\title{
Modeling a PV-FC-Hydrogen Hybrid Power Generation System
}

\author{
Shabnam Javadpoor \\ Department of Electrical Engineering, Faculty of \\ Engineering, Urmia Branch, \\ Islamic Azad University Urmia, Iran
}

\author{
Dariush Nazarpour \\ Department of Electrical Engineering, Faculty of \\ Engineering, Urmia Branch, \\ Islamic Azad University Urmia, Iran
}

\begin{abstract}
Electrical grid expansion onto remote areas is often not cost-effective and/or technologically feasible. Thus, isolated electrical systems are preferred in such cases. This paper focuses on a hybrid photovoltaic (PV)-hydrogen/fuel cell (FC) system which basic components include a PV, a FC, alkaline water electrolysis and a hydrogen gas tank. To increase the response rate, supercapacitors or small batteries are usually employed in such systems. This study focuses on the dynamics of the system. In the suggested structure, the PV is used as the main source of power. The FC is connected to the load in parallel with the PV by a transducer in order to inject the differential power while reducing power generation in relation to power consumption. An electrolyzer is used to convert the surplus power to hydrogen. This study studies a conventional hybrid photovoltaichydrogen/fuel cell system to evaluate different loading behaviors. Software modeling is done for the suggested hybrid system using MATLAB/SIMULINK.
\end{abstract}

Keywords-dynamic modeling; fuel cell; generated power; hybrid; photovoltaic system; electrolyzer; hydrogen; simulink

\section{INTRODUCTION}

Solar systems that convert sunlight directly into electricity are sustainable, silent, low-maintenance, eco-friendly, clean and efficient independent of the size of generator. Photovoltaic (PV) cells can be used connected to the grid or as isolated power sources. Electrical energy of photovoltaic systems is injected to electricity grid using electrical equipment of DC to AC voltage transducer as well as inverters connected to the grid. Functionally, the power generated by solar PV generators considerably changes due to climate changes; this may cause many problems such as extreme frequency deviation in the grid. Considering the significance of system reliability, it is proposed that PVs must be associated with another power source or backup unit, particularly in grid-independent systems, for continuous power generation. One solution to the problem of hybrid PV units and other energy sources such as diesel generators is the use of fuel cells (FC) or a backup battery [1]. Diesel generator guarantees continuous power generation [2]. A fuel cell is an electrochemical system which converts chemical energy directly into electrical energy. The efficiency of fuel cells is higher than that of internal combustion engines.. Fuel cells are a rather interesting option for hybrid PV generators due to their good efficiency, proper response time, production in modules and packs, and flexibility.
The system studied in this paper is a hybrid off-grid system based on PVs, FCs, alkaline water electrolysis and hydrogen gas storage tanks. The required hydrogen is achieved through electrolysis [3]. Results for a full day's supply of disposable and grid-independent load are acquired and discussed.

\section{INTRODUCTION TO PV SYSTEMS}

The dynamics model of a photovoltaic system is given by:

$$
I_{s}=I_{p h}-I_{d}-I_{s h}
$$

Where $I_{p h}$ is the flow of each photon in the solar cell photovoltaic systems, $I_{d}$ is diode current losses and $I_{s h}$ is the shunt current in the electrical equivalent circuit of a solar cell. Cell short circuit current is determined by $\mathrm{I}-\mathrm{V}$ characteristic of the solar cell for the output current of zero $\mathrm{I}_{0}=0$ (no-load).

$$
I_{p h}=P_{1} E_{s}\left[1+P_{2}\left(E_{s}-E_{0}\right)+P_{3}\left(T_{j}-T_{0}\right)\right]
$$

In (2), $P_{1}, P_{2}, P_{3}$ are the empirical constants, where $P_{1}$ is the photon current generation area in sunlight and $P_{2}, P_{3}$ are the correction coefficients in relation to the type of sunlight and ambient temperature. In (2), $T_{j}$ can be considered as the connection heat of the cells provided by (3). [5]

$$
T_{j}=T_{a}+\frac{E_{s}}{800}(N O C T-20)
$$

Where $T_{a}$ is the ambient temperature and NOCT is the normal cell performance temperature.

$$
I_{d}=I_{s a t} \cdot\left[\exp \left(\frac{e_{0}}{a_{f} N_{s} k} \cdot \frac{U_{s}+R_{s} I_{s}}{T_{j}}\right)-1\right]
$$

Equation 4 is about the amount of the losses in diode, where in this regard $I_{\text {sat }}$ is the saturation current, $N_{s}$ the is number of cells in series and $k$ is Boltzmann's constant, as the saturation current equation is shown in the form of (5) [6].

$$
I_{s a t}=P_{4} T_{j}^{3} \exp \left(-\frac{E_{g}}{k T_{j}}\right)
$$

Where $E_{g}$ is the gap energy and value for $I_{s h}$ can be ultimately written as in (6). $R_{\text {sh }}$ is the shunt resistor value [7]. 


$$
I_{s h}=\frac{U_{s}+R_{s} I_{s}}{R_{s h}}
$$

\section{PV MODELING}

The different equations presented previously were modeled in SIMULINK through various models depicted in Figures 1 to 6 (representing the equations presented previously).

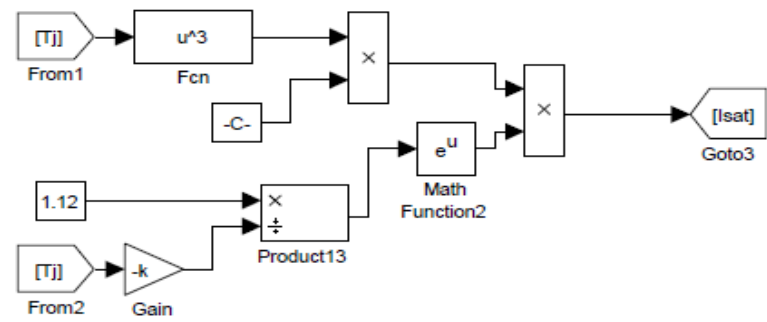

Fig. 1. The PV saturated currents model

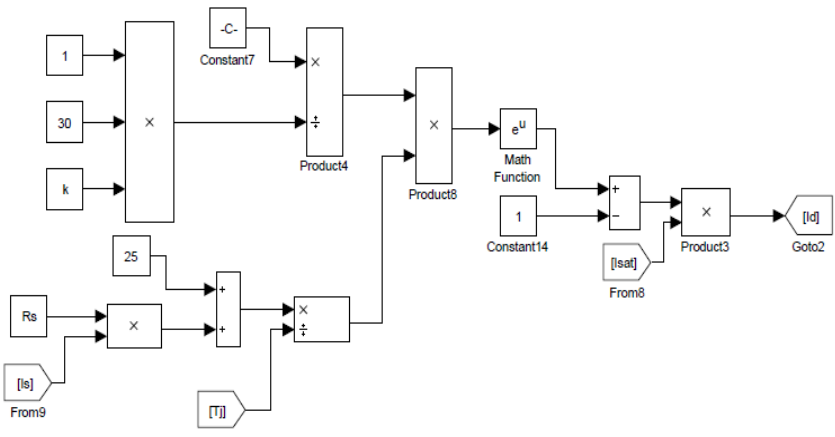

Fig. 2. The PV diodes losses model

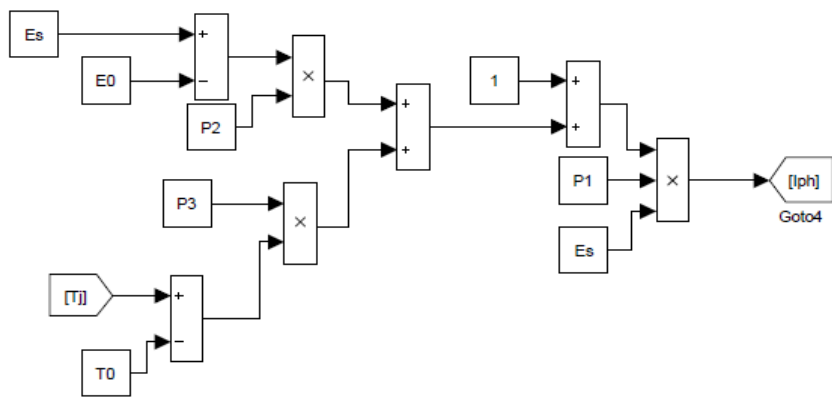

Fig. 3. The PV current model

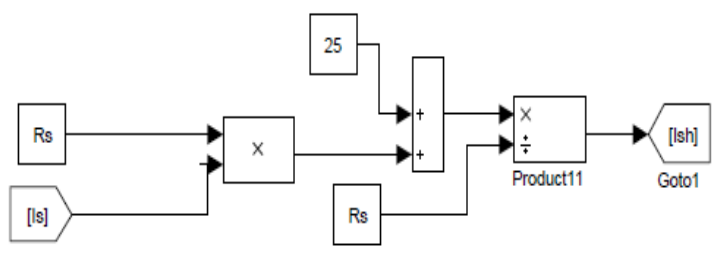

Fig. 4. The PV shunt current model

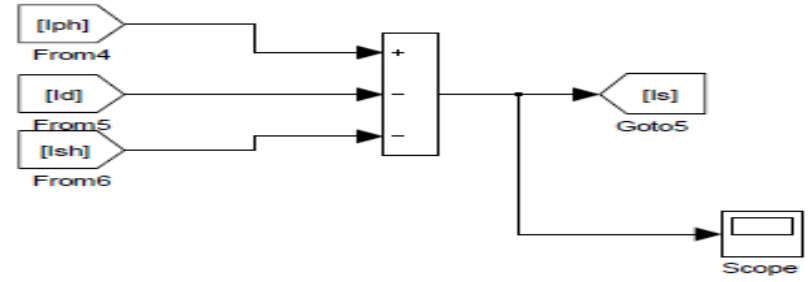

Fig. 5. The PV overall current output model

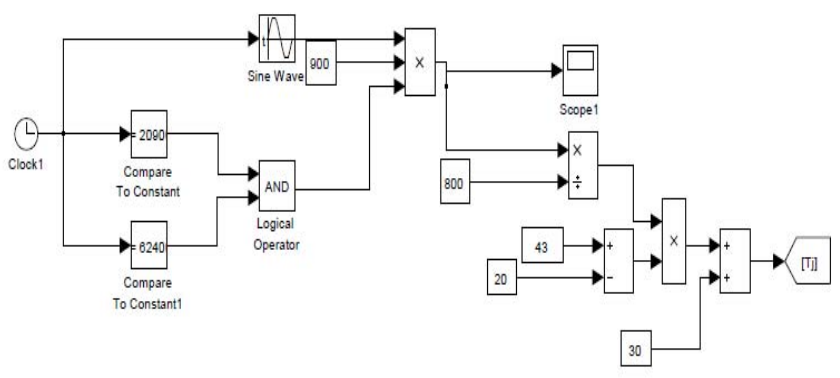

Fig. 6. The model of ambient air and PV cells' heat

\section{MODELS AND RESULTS}

\section{A. PV modeling results}

Results of the modeling of photovoltaic system were considered overnight (model output). Regarding the existence of heat in the temperature and sunlight radiation during 2000060000 seconds (overnight), the output curves show the sunlight radiation condition and ambient temperature (Figure 7). In addition, the overnight results were considered as 86400 seconds [8-9]. The extracted curve shows the result of sunlight condition, as the existed curves represent the sunlight condition at different times overnight and another one shows the thermal conditions at the ambient temperature around the cell. Figure 8 shows the generated current, voltage and power through the solar cell overnight. As shown, when the rate becomes higher or lower, the values changes accordingly.

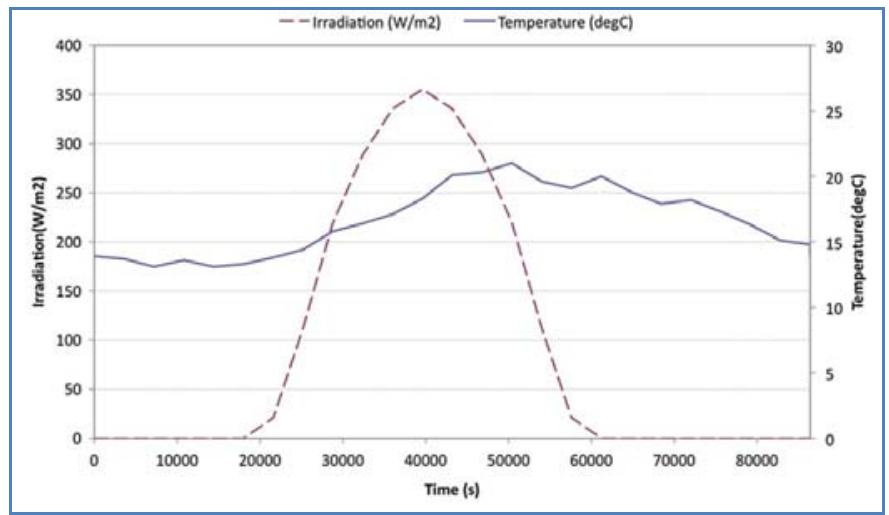

Fig. 7. Status of sunlight radiation and ambient temperature overnight 


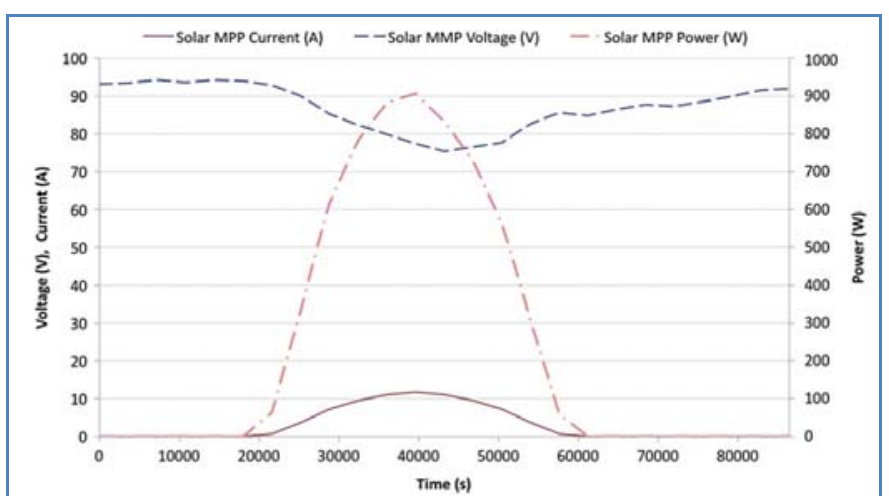

Fig. 8. Graph of output current, voltage and power generated by the solar cell during a day

\section{B. Fuel Cell model}

The dynamic model of a fuel cell is given by:

$$
U_{F C}=U_{o c v}-\eta_{a c t}-\eta_{c o n c}-\eta_{o h m}
$$

Open circuit voltage of the fuel cell is considered as a change in Gibbs free energy for the reaction of hydrogen and oxygen [10-11].

$$
U_{\text {ocv }}=1.2297+(T-298.15) \frac{\Delta S_{0}}{2 F}+\frac{R T}{2 F} \operatorname{In}\left(\frac{P_{H 2} \times P_{O_{2}}^{1 / 2}}{P_{0}^{3 / 2}}\right)
$$

In the above equation, UOCV is related to the activation potential of a cell of fuel cell caused by the reaction at the electrode surface [12].

$$
j=j_{0}\left[e^{(2 \alpha F / R T) \eta_{a c t}}-e^{(2(1-\alpha) F / R T) \eta_{a c t}}\right\rfloor
$$

The model of the hybrid system is presented in Figure 9 and the two subsystems are further shown in Figures 10 and 11.

\section{Results}

The polarization curve represents a comparison between the simulation and theoretical values (Figure 12). The graph shows the differences between these outputs and a good agreement is shown. Figure 13 shows the current at the outlet of the fuel cell depending on its maximum and minimum performance. Comparison of the predicted output power and the response of the output power measured from the fuel cell system at the same conditions is shown in Figure 14. Comparison of both curves also shows good agreement. Further, the sample load or the consumed power connected to fuel cell is just 900 watts whereas the power generated by a fuel cell may reach 6000 watts. Figure 17 shows the output values of current, voltage and power of the fuel cell when the fuel cell is used as a power source.

\section{Electrolyzer model}

The voltage model for the electrolyzer system is shown in Figure 16. Figure 17 shows the input/output model. Figure 18 shows the dynamics of the Ohmic potential in the electrolyzer system, directly affected by the value of hydrogen generated in electrolyzer.

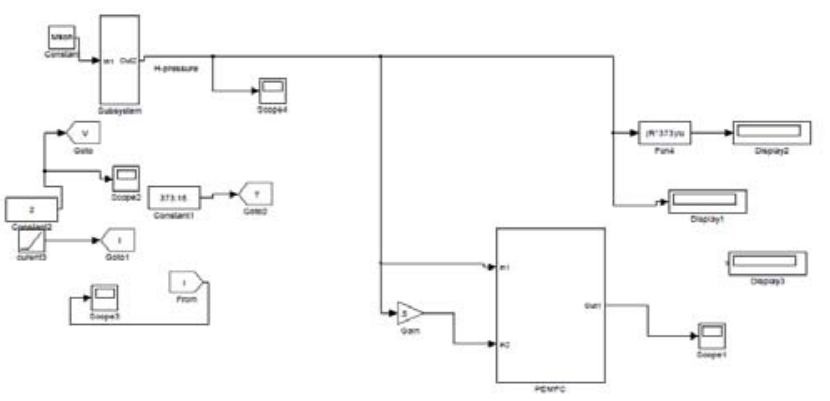

Fig. 9. The FC model with electrolyzer system and hydrogen storage tank

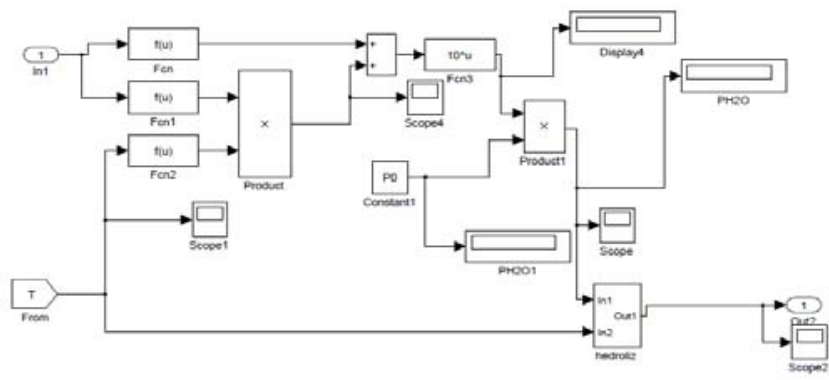

Fig. 10. The electrolyzer model

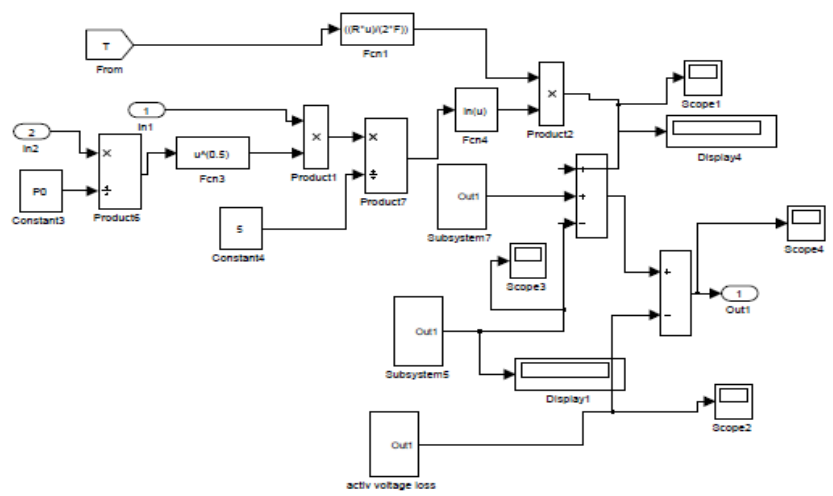

Fig. 11. The hydrogen storage tank system model

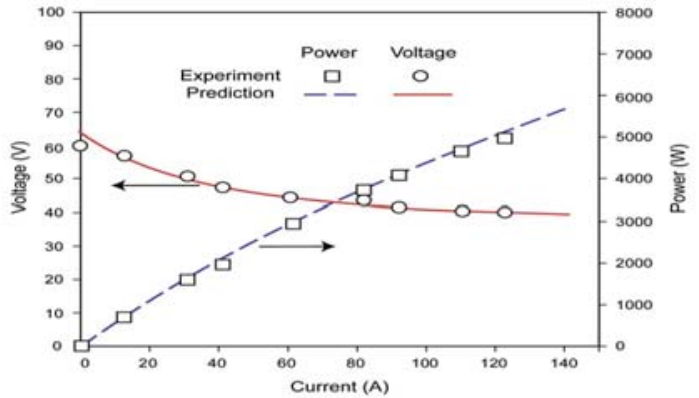

Fig. 12. Values for current, voltage and output power in the polarization curve of experimental and predicted results 


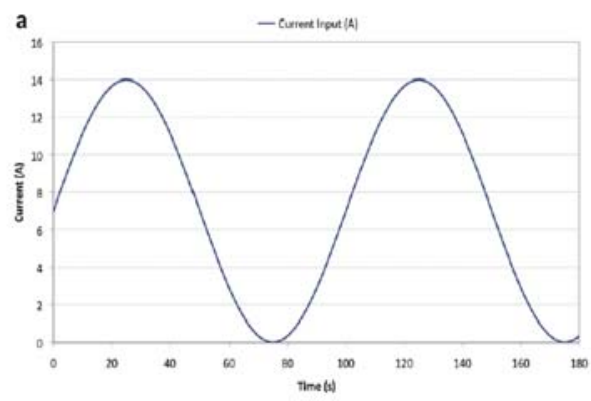

Fig. 13. The extracted value of the current obtained by the fuel cell at the maximum and minimum times of the system performance

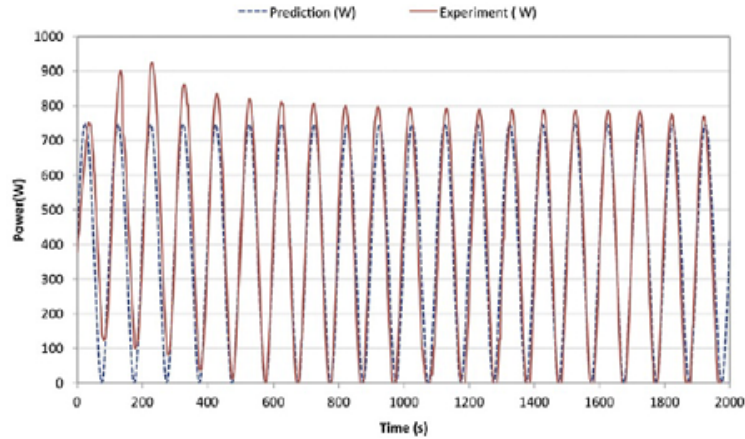

Fig. 14. Comparison of the predicted output power and the response of the output power measured from the fuel cell system at the same conditions

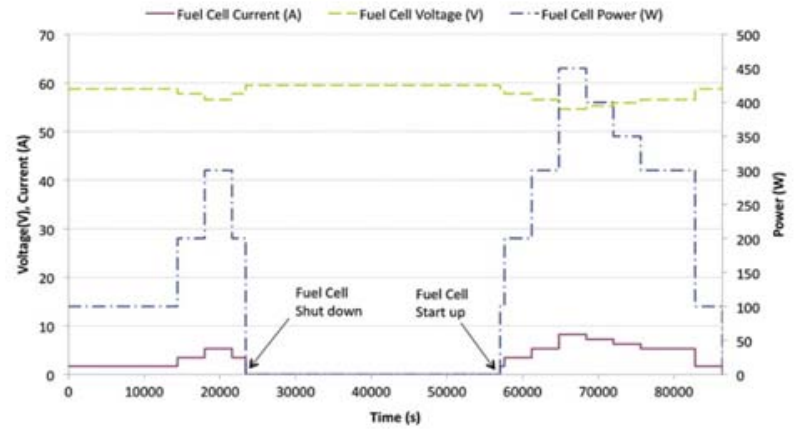

Fig. 15. Values of the current output, voltage and power at during turning on and off of the fuel cell system

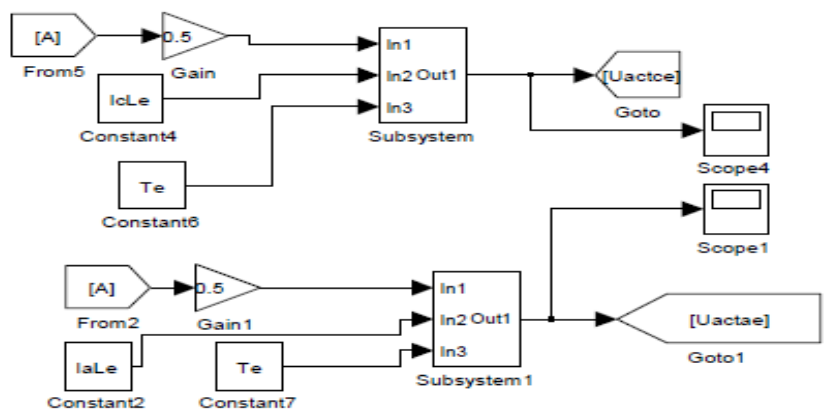

Fig. 16. The model of the actual voltage in the electrolyzer system

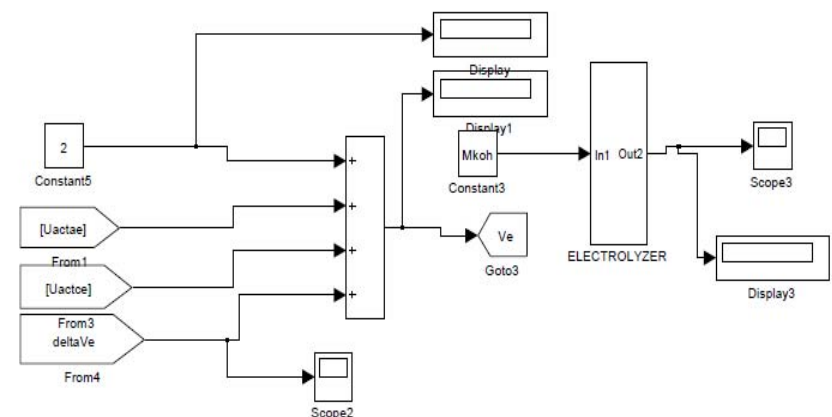

Fig. 17. The electrolyzer input/output model
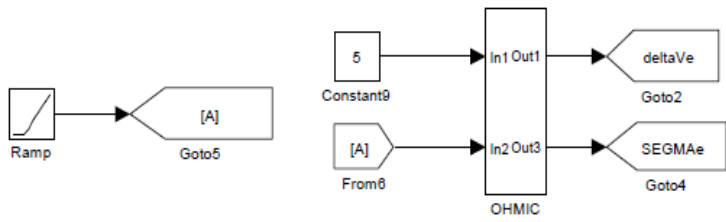

Fig. 18. The electrolyzer Ohmic potential model

\section{E. Results}

The electric dynamics of the electrolyzer is shown in Figure19. Figure 20 represents the hydrogen flow at the time of production and consumption through the electrolyzer and a fuel cell. Figure 21 shows the volume of hydrogen flow and pressure alterations in the liquid hydrogen tank at the storage and consumption times.

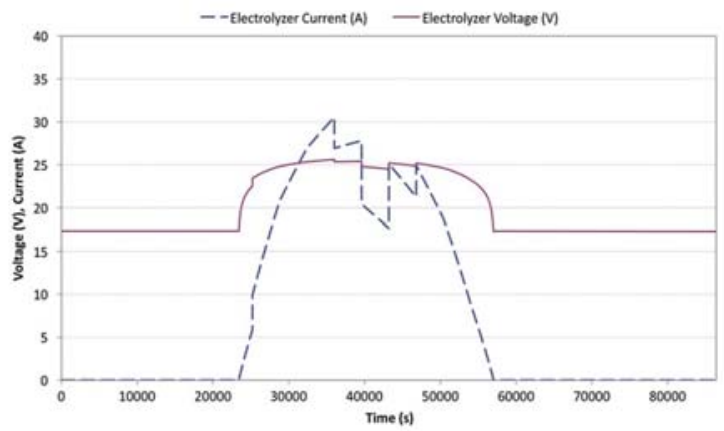

Fig. 19. Electrical dynamics of the electrolyzer system

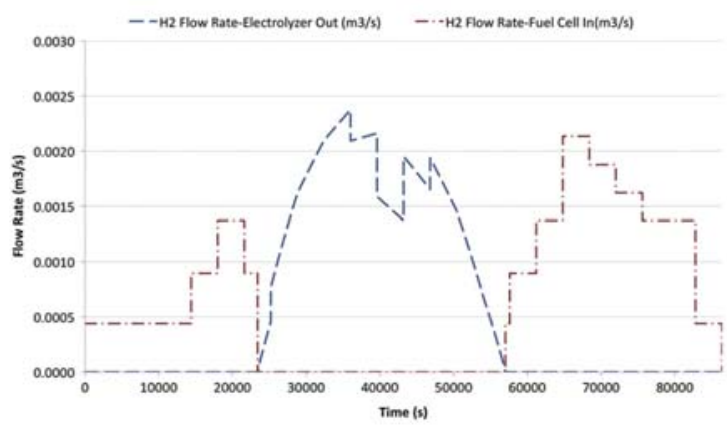

Fig. 20. Velocity of hydrogen flow at the times of production and consumption via electrolyzer and fuel cell 


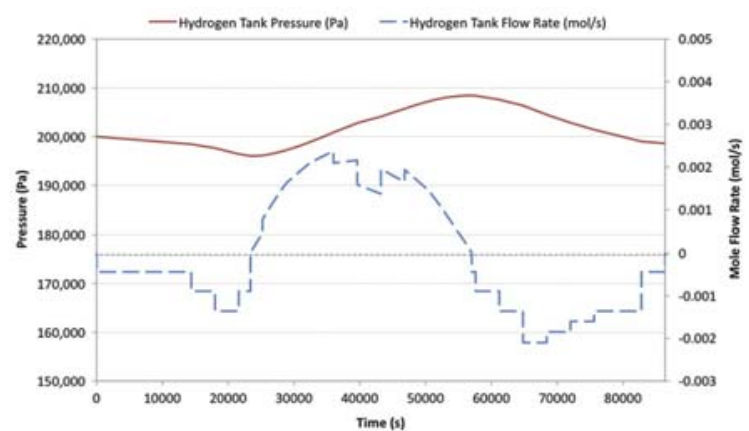

Fig. 21. Volume of the hydrogen flow and pressure alterations in the liquid hydrogen tank at the times of storage and consumption

\section{CONCLUSION}

The presented study focuses on modeling an isolated hybrid power generation system. The suggested structure used PV as the main power source. A fuel cell is connected to in parallel in order to compensate the power balance. An electrolyzer was used to convert the surplus power to hydrogen. The produced hydrogen is stored in tanks and used as fuel in the fuel cell. The theoretical basis and SIMULINK models are shown and results are presented and discussed.

\section{REFERENCES}

[1] K. Agbossou, M. Kolhe, J. Hamelin, T. K. Bose, "Performance of a stand-alone renewable energy system based on energy storage as hydrogen”, IEEE Transactions on Energy Conversion”, Vol. 19, No. 3, pp. 633-640. 2004

[2] C. Wang, M. H. Nehrir, "Power management of a stand-alone wind/photovoltaic/fuel cell energy system", IEEE Transactions on Energy Conversion, Vol. 23, No. 3, pp. 957-967, 2008

[3] K. S. Tam, S. Rahman, "System Performance Improvement Provided by a power conditioning subsystem or central station photovoltaic fuel cell power plant”, IEEE Transactions on Energy Conversion, Vol.3, No. 1, pp. 64-70, 1998

[4] T. Senjyu, T. Nakaji, K. Uezato, T. Funabashi, “A hybrid power system using alternative energy facilities in isolated island", IEEE Transactions on Energy Conversion, Vol. 20, No. 2, pp. 406-414, 2005

[5] C. Wang, M. H. Nehrir, "Power management of a stand-alone wind/photovoltaic/fuel cell energy system", IEEE Transactions on Energy Conversion, Vol. 23, No. 3, pp. 957-967, 2008

[6] S. Arul Daniel, N. Ammasai Gounden, "A Novel Hybrid Isolated Generating System Based on PV Fed Inverter-Assisted Wind-Driven Induction Generators”, IEEE Transactions on Energy Conversion, Vol. 19, No. 2, pp. 416-422, 2004

[7] M. R. Patel, Wind and Solar Power Systems: Design, Analysis, and Operation, Second Edition, Published by CRC Press Taylor \& Francis Group, 2006

[8] U. S. Government Printing Ofice, Basic Photovoltaic Principles And Methods, Washington, DC, 1982

[9] F. A. Farret, M. Godoy Simoes, Integration of alternative sources of energy. John Wiley \& Sons. 2006.

[10] A. D. Hansen, P. E. Sorensen, L. H. Hansen, H. W. Bindner, Models for a Stand-Alone PV System, Technical University of Denmark, 2001

[11] T. Esram, J. Kimball, P. Krein, P. Chapman, P. Midya, "Dynamic Maximum Power Point Tracking of Photovoltaic Arrays Using Ripple Correction Control”, IEEE Transactions on Power Electronics, Vol. 21, No. 5, pp. 1282-1291, 2006

[12] EG\&G Technical Services, Inc., Fuel Cell Handbook, U.S. Department of Energy, 2004 